\title{
РОЛЬ СУДОВОЇ ПРАКТИКИ ВЕРХОВНОГО СУДУ У ПРОЦЕСІ ПРАВОЗАСТОСУВАННЯ ЦИВІЛЬНО- ПРАВОВИХ НОРМ
}

\author{
ШИШКА Наталія Віталї̈вна - кандидат юридичних наук, доцент кафедри \\ цивільно-правових дисциплін факультету № 4 Харківського національного \\ університету внутрішніх справ \\ ORCID ID: 0000-0002-3396-4530 \\ УДК 347.91/.95 \\ DOI 10.32782/NP.2021.2.23
}

У статті, на основі аналізу норм чинного цивільного законодавства, правової позицй Европейсъкого суду з прав людини та наукових підходів вітчизняних та зарубіжних учених проаналізовано та визначено місие і роль судової практики Верховного Суду у прочесі правозастосування ицвільно-правових норм. Зроблено висновок, що судова практика Верховного Суду відіграє важливу роль у прочесі правозастосування иивільно-правових норм, проте, у порівнянні з иливільно-правовими нормами, їх роль є другорядною. Виходячи з того, що відповідно до ЦК України, судова практика Верховного Суду не відноситься до джерел ицивільного права, то ие дало авторові підставу зробити аргументацію, що такий суд не має здатність здійснювати нормотворчу діяльність, зокрема створювати, змінювати чи скасовувати иивільно-правові норми. Доведено, що Верховний Суд наділений лише можливістю проводити обічійне тлумачення (роз'яснення) правових норм, а його судова практика є обічійними актами судового тлумачення (роз'яснення) правових норм.

Встановлено, що головна роль судової практика Верховного Суду полягае в усуненні проявів правової невизначеності у правозастосуванні. Доведено, шо така судова практика сприяе реалізаий приниипу рівності всіх громадян перед законом та судом, а також вона забезпечує майбутню сталість $і$ єдність судової практики.

Виявлено, шо правову позичію Верховного Суду, яка бактично набуває ознак норми права, слід розглядати як таку, що несумісна 3 принципом верховенства права, оскільки своєю регулятивною силою вона створюе у праві стан правової невизначеності.

Ключові слова: верховенство права, судова практика, Верховний суд, цивільноправова норма, акти судового тлумачення (роз'яснення) правових норм.

Постановка проблеми

В умовах оновлення цивільного законодавства одним із важливих аспектів такої ревізії $є$ приведення цивільно-правових норм до вимог правової визначеності [1, с. 223], особливо, коли це стосується процесу правозастосування норм цивільного права. Оскільки, від якості правового регулювання відповідними нормами права залежить і якість правозастосування певними суб'єктами права, переважно суддями, які під час здійснення правосуддя стикаються із проблемами правильного застосування норм матеріального та процесуального права.

Правозастосування в державі напряму залежить від двох важливих факторів. Перший - це казус (випадок), який відповідно до приписів закону підпадає під певну модель правового регулювання. Другий - це норма, яка застосовується до певного казусу. Проте, щодо останнього, то в правозастосовному процесі не завжди все є достатньо зрозумілим, особливо коли перед відповідними суб'єктами права, зокрема суддями, постає досить складне запитання: яка норма має застосовуватися до певного випад- 


\section{Цивільне, підприсмницьке, господарське та трудове право}

ку та як саме? Якщо виникають складнощі правозастосування, то значну роль у цьому відіграє ВС. Адже, лише на ВС сьогодні покладена роль у сталості та єдності судової практики, з метою забезпечення однакового застосування норм права судами системи судоустрою України. Як відомо, у переважній більшості, однакове застосування норм права судами досягається за рахунок зроблених висновків, викладених у постановах BC. У цьому аспекті ЄСП $\Lambda$ у своїх рішеннях вказує, що роль найвищих судових інстанцій держави полягає: у наданні керівних рекомендацій на майбутне (pro futuro) [2]; у виправленні непослідовності/суперечливості судової практики нижчих судів, у тому числі і розбіжностей, які існують між різними палатами найвищого суду і остаточному визначенні тлумачення законодавчого положення з метою усунення проявів правової невизначеності у певній сфері [3, п. 49]; у забезпеченні рівномірного та цілісного застосування закону [4, п. 35]. Усе це, як підкреслюється у рішеннях $\mathrm{ECП} \curlywedge$, спрямовано на забезпечення єдності судової практики, і в такий спосіб - підтримання громадської довіри до судової системи [5, пп. 34-38], а неспроможність Вищого суду впоратись із цим завданням може призвести до наслідків, несумісних з вимогами статті 1 Першого протоколу до Конвенції про захист прав і основних свобод людини [4, п. 35].

У зв'язку із цим виникає досить важливе питання: яку роль відіграє практика $\mathrm{BC}$ у процесі правозастосування норм цивільного права? Тобто висновки, які зроблені та викладені в рішеннях ВС, є певним інструментом, який лише роз'яснює як та яким чином має застосовуватися певна норма права до конкретного випадку, чи вони також здатні регулювати цивільні відносини за рахунок добудови права?

\section{Аналіз останніх досліджень і публікацій}

Проблема визнання судових рішень найвищих судових інстанцій як невід'ємний інструмент у процесі правозастосування постійно цікавила та продовжує цікавити вчених-юристів. Однак, незважаючи на підвищену увагу до аналізованої проблеми, спо- стерігаються розбіжності з широкого кола питань, що стосуються судової практики. Серед науковців, які займалися питанням ролі та значення судової практики найвищих судових інстанцій держави, слід виокремити: Д. Ю. Хорошковську, С. В. Шевчука, І. В. Спасибо-Фатєєву, Д. Д. Ауспеника, С. П. Погребняк, I. В. Борщевського, О. Р. Дашковську, М. В. Мазур, Б. В. Малишева, Н. М. Пархоменко, О. В. Петришина, В. В. Решоту, М. В. Цвіку, Р. А. Майданика, О. Р. Шишку та ін.

Метою статті є з'ясування ролі судової практики ВС у процесі правозастосування норм цивільного права.

\section{Виклад основного матеріалу дослідження}

Зростання обсягів законотворчості у сфеpi приватного права у будь-якому випадку на сьогодні не задовольняє потреби суспільства, особливо - коли це стосується якості правової норми. Судова практика ВС відіграє у цих випадках досить важливу роль. Адже вона є орієнтиром для судів нижчої інстанції (першої та апеляційної) при застосуванні норм матеріального та процесуального права для забезпечення єдності судової практики. Тому правова позиція ВС відіграє важливу роль у процесі правозастосування норм права, у тому числі і норм цивільного права.

Правові системи різних держав неоднаково визначають місце правових позицій найвищих судових інстанцій держави. Так, Англо-саксонська правова сім'я заснована на доктрині stare decisis, згідно з якою судді зв’язані при вирішенні справ раніше прийнятими прецедентами. Тобто це правило, згідно з яким логічні силогізми, на яких суд засновував своє попереднє рішення, є обов'язковим у всіх наступних випадках, у яких факти по суті - однакові (stare decisis et non quieta movere, «залишатися на вирішенні і не порушувати спокою») [6, с. 521]. Якщо зводити до більш простішої форми, то суть такої доктрини зводиться до того, що однакові чи подібні справи повинні вирішуватися однаково [7]. У країнах романо-германського права, до якої відно- 
ситься і Україна, застосовується доктрина, яка є аналогічна французькій јurisprudence constante (усталена судова практика), за якою «низка раніше прийнятих та узгоджених судових рішень розглядається як переконливий доказ правильного тлумачення правової норми» [8, р. 783; 9, с. 395-396]. Для такої доктрини характерним є те, що усталена практика формується через цілу низку рішень, які у своєму взаємозв'язку створюють певну послідовність справ. Така практика не є обов'язковою до застосування, але може використовуватись з огляду на той авторитет, що вона отримала [10, с. 99]. Дійсно, підтвердженням наявності в законодавстві України наведеного правового концепту - є, наприклад, ч. 4 ст. 263 ЦПК України, у якій визначено, що при виборі і застосуванні норми права до спірних правовідносин суд враховує висновки щодо застосування відповідних норм права, викладені в постановах Верховного Суду. Тобто наведена норма, з одного боку, вказує на важливість висновків, які зроблені Верховним Судом щодо застосування відповідних норм права, а з іншого - така норма не вказує на їх обов'язковість у застосуванні, на відміну від попереднього правового підходу, який містився у старій редакції ЦПК України, а саме у ст. 360-7. Так, у ній було передбачено, що висновок Верховного Суду України щодо застосування норми права, викладений у його постанові, є обов'язковим для всіх суб'єктів владних повноважень, які застосовують у своїй діяльності нормативноправовий акт, що містить відповідну норму права. Висновок щодо застосування норм права, викладений у постанові Верховного Суду України, має враховуватися іншими судами загальної юрисдикції при застосуванні таких норм права. Суд має право відступити від правової позиції, викладеної у висновках Верховного Суду України, з одночасним наведенням відповідних мотивів. Тобто такий правовий підхід був щось середнє між доктриною stare decisis та доктриною јurisprudence constante.

При цьому, у межах доктрини jurisprudence constante, варта уваги позиція P. А. Майданика. Ним зазначається, що судовою практикою не можна вважати будь- яке роз'яснення Вищих судових органів: рішення суду, ухвалу касаційної інстанції чи навіть сукупність рішень по конкретній групі справ. Зміст судової практики становлять тільки ті правоположення юрисдикційних органів, які конкретизують норми права. Такі правоположення можуть виникати двома шляхами: 1) внаслідок подолання судовими органами прогалин у праві;2) внаслідок здійснення судовими органами конкретизації норм права. При цьому, у діяльності суду слід розрізняти індивідуалізацію норми права (тобто розповсюдження іiі змісту на окремих осіб, події, факти певної справи) від конкретизації норми права, внаслідок якої виникає правоположення - новий деталізований припис загального характеру [11].

Щодо місця правових позицій найвищих судових інстанцій у процесі правозастосування в країнах романо-германського права, то в науці, з цього приводу, існують неоднакові правові підходи.

Так, доцільно згадати вислів Ф. Бекона, який зазначив, що суддям слід пам'ятати, що їхньою справою $\epsilon$ «jus dicere», а не «jus dare» тобто тлумачити закони, а не створювати та видавати їх [12, с. 476]. Інший дослідник, Б. В. Малишев, зазначає, що в результаті тлумачення судом створюються положення, у яких просто роз'яснюється зміст норм, вказані положення є їхнім логічним висновком, а в результаті конкретизації створюються нові правоположення, які деталізують норми закону. Зазначається, що конкретизація властива правовій системі, причому вона може здійснюватись як нормотворчими органами (у вигляді видання підзаконних актів), так і судами [13].

А. В. Журавльов вважає, що судова практика судів загальної юрисдикції, окружних адміністративних судів в Україні офіційно не визнається джерелом права, проте нижчі судові інстанції завжди намагаються наслідувати практику Вищих судів у розв'язанні аналогічних справ, вона виступає орієнтиром для них» $[14$, с. 6]. На основі цього висновку В. В. Решота робить конкретизований висновок, що, безумовно, практика судів відіграє роль джерела переконливого характеру, що дозволяє судді виявити тен- 


\section{Цивільне, підприсмницьке, господарське та трудове право}

денції вирішення тих чи інших категорій справ, порядок застосування судом джерел права, взнати позицію вищестоящих судів щодо цього. Звідси рішення судових органів, які не 6 обов'язковими в застосуванні, відіграють допоміжну, інформативну функцію для судів при розгляді та вирішенні справ [15, с. 253].

В. П. Реутов робить висновок про те, що приписи, які містяться в постановах Верховного Суду, фактично носять характер офіційного тлумачення (роз'яснення) правових норм, часто розширювального або обмежувального характеру, або тлумачення 3 елементами правотворчості [16, с. 336].

Іншу позицію займає В. В. Ільков, який акцентує увагу на тому, що судовою практикою тлумачаться та створюються певні правоположення, які за своєю суттю є джерелами права

C. В. Шевчук, займаючи схожу позицію, вважає, що коли йдеться про практику суду як джерело права, то, виходячи з досвіду країн західної демократії, слід зазначити, що будь-яке рішення суду не може мати прецедентний характер, а тому й слугувати джерелом права. Особливо це стосується такого феномену, як постанови Верховного Суду України, оскільки вони мають загальнообов'язковий характер і за своїм змістом нагадують акти правотворчості. Такі акти слід називати актами «квазіпрецедентного права». Прецедентне право формується у результаті розгляду судом вищої юрисдикції конкретної справи, а не встановлюється як результат абстрактних узагальнень судової практики щодо певної категорії справ. Ця специфіка «від конкретного до загального» пов'язана з професійним обов'язком судів здійснювати правосуддя, що передбачає також обов'язкову вмотивованість та обгрунтованість судових рішень [17, c. 17].

Д. Д. Ауспеник вважає, що незалежно від того визнаються чи не визнаються за судовою практикою, у тому числі і за постановами Пленуму Верховного Суду України, властивості джерел права, фактично вони такими $\epsilon$ і мають велике значення для вітчизняної правової системи [18, с. 11].
I. В. Спасибо-Фатєєва піддає сумніву невизнання за судовою практикою можливості створення правових норм і наводить низку аргументів. Так, учена наголошує, що відмова від розуміння судової практики як джерела права має істотні негативні сторони, які проявляються також у тому, що суди «звільнені» від обов'язку дотримуватися будь-якої єдиної позиції, виробленої з тих чи інших питань доти, поки вищими судовими інстанціями не будуть дані відповідні роз'яснення або зроблені узагальнення. Відкидання значення судової практики як джерела права також не припустимо, тому що це значною мірою збіднило 6 право, знову звело 6 його на позиції позитивізму й не відображало 6 існуючої дійсності [19, с. 84-87]. Також вчена наголошує, що, застосовуючи норму законодавства при вирішенні конкретного спору, суд створює норму права. У свою чергу, це сприяє уніфікації підходів до вирішення судами спорів, надає значимості рішенням судів як інститутів, здатних приймати рішення, керуючись принципами права, і тим самим виносити справедливі рішення. Такі дії суддів свідчать про те, що вони своїми рішеннями створюють правові норми [20, c. 54].

О. Р. Шишка хоча і відстоює позицію, що висновки Верховного Суду, виходячи із сьогоднішнього стану правового регулювання, не можуть бути джерелами права, проте у своєму дослідженні зазначає, що висновки найвищого суду набувають правотворчого характеру і виступають фактично джерелом регулювання цивільних відносин (таким собі «завуальованим» прецедентом), лише за умов, коли вони не відповідають дійсній букві закону. Тобто за обставин, коли висновки щодо застосування відповідних норм права, викладених у постановах найвищого суду, нівелюють дійсний зміст норм права, створюється технічна підміна частини правової матерії, набувають значення інтерпретаційно-правові положення, що висловлені судом у відповідних актах офіційного тлумачення подібно до того, як би ми їх дійсно розглядали як джерело права [21, с. 219-220].

Також, доцільно навести і позиціюБ. Кардозо, який свого часу писав, що суд творить право там, де відсутні закони, пре- 
цеденти та інші формальні джерела права [22]. Дійсно, з останньою думкою слід погодитись, але $з$ єдиним застереженням, що така діяльність суду можлива лише за тих обставин, коли закон надає судам правотворчі можливості. Якщо брати правову систему України, то ВС така можливість сьогодні не надана, оскільки він, відповідно до чинного законодавства, лише має застосовувати норми при вирішенні конкретної справи, а отже, повинен діяти згідно із законом та відповідно до закону. Дії суду які суперечать наведеному правилу, йдуть усупереч принципу верховенства права, незалежно від того, які у нього наміри - добрі чи погані.

Варто також звернути увагу і на прак-

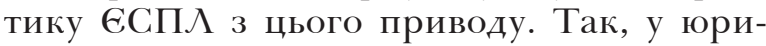
дичній літературі вказується [23, с. 54], що концепція «закон» (в англомовному варіанті - law), як зазначає $\mathrm{ECП} \Lambda$, включає як статутне право (в англомовному варіанті - statutory law також розуміється як право, виражене в законодавчих актах), так і прецедентне право («суддівське право»). У зв'язку з цим, суд завжди розуміє термін «закон»у його «сутнісному», а не у «формальному» сенсі. А тому такий термін охоплює як «писане право», що включає, крім закону, також і законодавчі акти нижчого рівня, у тому числі нормативні заходи, які приймаються професійними регулювальними органами в межах делегованих їм незалежних нормотворчих повноважень парламентом, так і неписане право. Таким чином, зазначає $\mathrm{ECП} \lambda$, «закон» - це положення, що діють у тому вигляді, як їх розтлумачили компетентні суди [24, п. 83] у світлі нових практичних змін [25, п. 28]. При цьому, слід звернути увагу, що прецедентне право, безсумнівно, є дуже важливим джерелом права, але, як зазначається таким судом, є вторинним, тоді як «закон» (у розумінні статутного права) є первинним джерелом права [25, п. 27]. У цілому, Суд визнає «законом» ту систему джерел права, яка діє в державі-учасниці Конвенції [26, р. 303], за умови, що їх зміст відповідає необхідним для цього документа вимогам та не суперечить принципу верховенства права.
Наведене вказує, що в процесі правозастосування цивільно-правових норм, які містяться лише у відповідних, визнаних у державі джерелах регулювання цивільних відносин, відповідні суб'єкти мають також керуватися і практикою ВС України, яка за своєю суттю є лише актами офіційного тлумачення цивільно-правових норм, тобто певними легальними інструкціями, що роз'яснюють, які саме норми права та яким чином вони застосовуються до певного випадку. При цьому, слід мати на увазі, що судова практика ВС має другорядний характер та як джерело правозастосування має використовуватися лише у комплексі тоді, коли вона не створює стан правової невизначеності. Останнє стосується тих випадків, коли ВС, виходячи за межі закону, здійснюе не тлумачну діяльність, а правотворчу.

Така позиція підтверджується сьогоднішнім станом правового регулювання. Так, відповідно до ч. 1 ст. 36. Закону України «Про судоустрій і статус суддів» Верховний Суд є найвищим судом у системі судоустрою України, який забезпечує сталість та єдність судової практики у порядку та спосіб, визначені процесуальним законом. Також у ч. 2 зазначено, що Верховний Суд: здійснюе аналіз судової статистики та узагальнення судової практики; звертається до Конституційного Суду України щодо конституційності законів, інших правових актів, а також щодо офіційного тлумачення Конституції України; забезпечує однакове застосування норм права судами різних спеціалізацій у порядку та спосіб, визначені процесуальним законом; здійснюе інші повноваження, визначені законом. У ч. 2 аналізованого закону слід звернути увагу на те, що Верховний Суд «забезпечує однакове застосування норм права ...». Тут виникає питання: чи здатні правові позиції Верховного Суду регулювати цивільні відносини? Наприклад, для забезпечення однакового застосування однієї цивільно правової норми, що міститься в законі, чи може Верховний Суд своєю діяльністю створюе іншу?

Важливо відмітити, що відповідно до ст. 263 ЦПК України судове рішення пови- 


\section{Цивільне, підприсмницьке, господарське та трудове право}

нно грунтуватися на засадах верховенства права, бути законним і обгрунтованим. При цьому, законним є рішення, ухвалене судом відповідно до норм матеріального права із дотриманням норм процесуального права. Відповідно, при вирішенні певної справи суд керується відповідними нормами матеріального права із дотриманням порядку передбаченим процесуальним законодавством. До цивільних відносин, виходячи із ст. 1 ЦК України, суд застосовує лише цивільне законодавство. Як зазначається у юридичній літературі, до цивільного законодавства відносяться: загальні засади цивільного законодавства; Конституція України; відповідні міжнародні договори; акти цивільного законодавства; договір та звичай [27, с. 205; 28, р. 114]. Несуперечним має бути висновок, що лише у цивільному законодавстві можуть міститися цивільно-правові норми. До цивільного законодавства, виходячи із вищенаведеного не відносяться судові рішення Верховного Суду, а тому, навряд чи такий суд може здійснювати нормотворчу діяльність, створювати цивільно-правові норми. Якщо Верховний Суд, відповідно до закону, не має здатність створювати цивільно-правові норми, то забезпечення однакового застосування норм права може бути реалізовано лише через тлумачну (роз'яснювальну) діяльність. Усе це дає підстави зробити висновок, що Верховний Суд наділений лише можливістю здійснювати офіційне тлумачення (роз'яснення) правових норм, а не створювати чи змінювати норми права. Висновки Верховного Суду, які підпадають під ознаки норми права, мають розглядатися як такі, що не сумісні 3 принципом верховенства права.

\section{Висновки}

Наведене свідчить, що судова практика Верховного Суду відіграє важливу роль у процесі правозастосування цивільно-правових норм. Їх головна роль - усунення проявів правової невизначеності у правозастосуванні. Поряд з цим, у порівнянні з цивільноправовими нормами, вони відіграють хоча i важливу роль у правозастосуванні, - але вторинну. Судова практика Верховного Суду є офіційними актами судового тлумачення (роз'яснення) правових норм, які забезпечують, на майбутнє, сталість та єдність судової практики, що відбувається за правилами цивільного та господарського судочинства. Крім цього, вона направлена на забезпечення дотримання принципу правової визначеності, сприяє реалізації принципу рівності всіх громадян перед законом і судом. Останне може бути досягнуто лише тоді, коли правові позиції ВС не створюють стан правової невизначеності та сприяють тому, що норми цивільного права застосовуються судами однаково в подібних цивільних та господарських справах щодо різних осіб. При цьому, висновки Верховного Суду, які підпадають під ознаки норми права, мають розглядатися як такі, що не сумісні з принципом верховенства права.

\section{1. Шишка О. Р. Рекодифікація} (оновлення) цивільного законодавства України як шлях до правової визначеності. Проблеми иивільного права та процесу : тези доп. учасників наук.-практ. конф., присвяч. 95-й річниці від дня народження О. А. Пушкіна (Харків, 22 травня 2020 р.). Харків : ХНУВС, 2020. с.223-230.

2. Висновок Консультативної ради європейських суддів № 20 «Про роль судів у забезпеченні єдності застосування закону» від 10 листопада 2017 року. URL: www.vru. gov.ua/content/file/Висновок_KPEC_20.pdf. Sa

3. Affaire Sine Tsaggarakis A.E.E. c. Grèce (Requête no. 19380/92): Judgment European Court of Human Rights, 23 mai 2019. HUDOC / European Court of Human Rights. URL: http://hudoc.echr.coe.int/eng?i=001-193088 (Last accessed: 17.12.2020).

4. Case of Serkov v. Ukraine (Application no. 39766/05): Judgment European Court of Human Rights, 7 July 2011. HUDOC/ European Court of Human Rights. URL: http:/hudoc. echr.coe.int/eng? $\mathrm{i}=001-105536$ (Last accessed: 17.12.2020).

5. Case of Albu and Others v. Romania (Application no. 34796/09): Judgment European Court of Human Rights, 10 May 2012. HUDOC / European Court of Human 
Rights. URL: http://hudoc.echr.coe.int/ eng?i=001-11080 (Last accessed: 17.12.2020).

6. Шишка О. Р. Чи володіє правова позиція Верховного Суду України силою правила stare decisis? Харківський національний університет внутрішніх справ: 25 років досвіду та погляд у майбутне (1994-2019 рр.) : зб. тез доп. на міжнар. наук.-практ. конф. до 25-річчя створення ун-ту (Харків, 22 листоп. 2019 р.). Харків, 2019. с. 521-523

7. Квятковська Б. І. Особливості судового прецеденту в англосаксонській та романо-германській правових сім'ях (порівняльний аналіз). Теорія $і$ практика правознавства. 2013. Вип. 1. URL: http://nbuv.gov. ua/jpdf/tipp_2013_1_3.pdf (дата звернення: 17.12.2020).

8. Algero M. The Sources of Law and the Value of Precedent: A Comparative and Empirical Study of a Civil Law State in a Common Law Nation. Louisiana Law Review. 2005. Vol. 65. P. 783.

9. Шевчук С. Судова правотворчість: світовий досвід і перспективи в Україні : монографія. К.: Реферат, 2007. 640 с.

10. Решота В. В. Правова природа рішень Верховного Суду України в адміністративному судочинстві у контексті забезпечення права на справедливий суд. Публічне право. 2015. № 2(18). С. 96-102.

11. Майданик Р. А. Цивільне право: Загальна частина. К. : Алерта, 2012. 472 с.

12. Бэкон Ф. Сочинения в двух томах. Т. 2. Москва: Мысль, 1978. 575 с.

13. Малишев Б. В. Судовий прецедент у правовій системі Англії (теоретикоправовий аспект) : дис. ... канд. юрид. наук : 12.00.01 / Київський національний ун-т ім. Тараса Шевченка. Київ, 2002. 230 с.

14. Журавльов А. В. Судові прецеденти в адміністративному судочинстві України: автореф. дис. ... канд. юрид. наук: 12.00.07. Запоріжжя, 2017. 18 с.

15. Решота В. В. Застосування джерел адміністративного права в судочинстві України : дис. ... докт. юрид. наук: 12.00.07 / ПВНЗ «Львівський університет бізнесу та права». Аьвів, 2019. 473 с.

16. Реутов В. П. О юридической природе и видах предписаний, содержащихся в актах высших судебных органов. Конкре- тизация права: теоретические и практические проблемъ : Материалы IX Международной научно-практической конференции. М.: РГУП, 2015. с.332-341.

17. Шевчук С. В. Рішення Верховного Суду України як джерело права (деякі аспекти дії прецедентного права в Україні). Вісник иентру суддівських студій. 2006. № 6. c. 16-19.

18. Ауспеник Д. Отечественная судебная практика как дополнительный источник права. Юридическая практика. 2004. № 23 (337). с. 10-12.

19. Спасибо-Фатєева I. В. Цивілістика: на шляху формування доктрин: вибір. наук. пр. Х. : Золоті сторінки, 2012. 696 с.

20. Спасибо-Фатеева И. В. Некоторые подходы к понятию источников права: в порядке постановки проблемы. Проблеми законності: респ. міжвідом. наук. зб. Харків, 2000. Вип. 42. С. 49-54.

21. Шишка О. Р. Висновки верховного суду України як «джерело» цивільного права : деякі вразливості та проблеми неспівпадіння з концептом ЦК України. Проблеми иивільного права та процесу: тези доп. учасників наук.-практ. конф., присвяч. світлій пам'яті О. А. Пушкіна (Харків, 24 трав. 2019 р.). Харків: ХНУВС, 2019. с. 217-222.

22. Cardozo B. N. The Nature of the Judicial Process. New Haven: Yale University Press, 1921. 180 p.

23. Шишка О. Р. Концепт терміна «закон» у практиці ЕСПА. Підготовка поліщейсъких в умовах ребормування системи МBC Украӥни : зб. наук. пр. конф. (м. Харків, 29 трав. 2020 р.). Харків : ХНУВС, 2020. с. 5456.

24. Case of Sanoma Uitgevers B. V. v. the Netherlands (Application no. 38224/03): Judgment European Court of Human Rights, 14 September 2010. HUDOC / European Court of Human Rights. URL: http://hudoc. echr.coe.int/eng?i=001-100448 (Last accessed: 17.12.2020).

25. Case of Huvig v. Frence (Application no. 11105/84): Judgment European Court of Human Rights, 24 April 1990. HUDOC / European Court of Human Rights. URL: http://hudoc.echr.coe.int/eng?i=001-57627 (Last accessed: 17.12.2020). 


\section{Цивільне, підприсмницьке, господарське та трудове право}

26. Jacobs F. G., White R. C. A. The European Convention on Human Rights. Oxford, 1996. P. 303.

27. Шишка О. Р. Цивільне законодавство України та його межі. Рекодифікація ицвільного законодавства Украӥни в умовах євроінтеграиійних проиесів : монографія. Київ : Норма права, 2020. с. 177-207.

28. Shyshka O. R. Civil legislation of Ukraine and its limits. Current issues of recodification of Ukrainian civil legislation : collective monograph. Lviv-Toruń : Liha-Pres, 2020. P. 104-117. References
1. Shyshka, O. R. $\begin{array}{r}(2020) . \\ \text { Rekodyfikatsiia (onovlennia) }\end{array}$ tsyvilnoho zakonodavstva Ukrainy yak shliakh do pravovoi vyznachenosti [Recodification (updating) of civil legislation of Ukraine as a way to legal certainty]. Problemy tsyvilnoho prava ta protsesu - Problems of civil law and procedure: Abstracts of Papers of participants of the scientific and practical conference dedicated to the 95th anniversary of the birth of O. A. Pushkin. (pp.223-230). Kharkiv: KHNVS [In Ukrainian].

2. Vysnovok Konsultatyvnoi rady yevropeyskykh suddiv № 20 «Pro rol sudiv $\mathrm{u}$ zabezpechenni yednosti zastosuvannya zakonu» [Opinion of the Advisory Council of European Judges № 20 «On the role of courts in ensuring uniform application of the law»] vid 10.11.2017 roku. Retrieved from www.vru. gov.ua/content/file/Висновок_KPEC_20.pdf. Sa [in Ukrainian].

3. Sine Tsaggarakis A.E.E. c. Grèce, nos. 17257/13, CEDH, 23 mai 2019. Retrieved from http://hudoc.echr.coe.int/ eng? $\mathrm{i}=$ 001-193088. [in French].

4. Serkov v. Ukraine, no. 39766/05, ECHR, 7 July 2011. Retrieved from http:// hudoc.echr.coe.int/eng?i=001-105536. [in English].

5. Albu and Others v. Romania, no. 34796/09, ECHR, 10 May 2012. Retrieved from http://hudoc.echr.coe.int/eng?i=001-11080. [in English].

6. Shyshka, O. R. (2019). Chy volodiye pravova pozytsiya Verkhovnoho Sudu Ukrayiny syloyu pravyla stare decisis? [ Does the legal position of the Supreme Court of Ukraine have the force of law stare decisis? ].
Kharkiv National University of Internal Affairs : 25 Years of Experience and Prospection (1994-2019) - Kharkivskyi natsionalnyi universytet vnutrishnikh sprav: 25 rokiv dosvidu ta pohliad u maibutnie (1991-2019 rr.) : Collection of Abstracts of Papers at the International Scientific and Practical Conference Dedicated to the 25th Anniversary of the University's Creation (pp.521-523). Kharkiv: KHUVS [In Ukrainian].

7. Kvyiatkovska, B. I. (2013). Osoblyvosti sudovoho pretsedentu v anhlosaksonskii ta romano-hermanskii pravovykh simiakh (porivnialnyy analiz). [Features of judicial precedent in the AngloSaxon and Romano-Germanic legal families (comparative analysis)]. Teoriia i praktyka pravoznavstva - Theory and practice of jurisprudence. Issue 1. Retrieved from http://nbuv. gov.ua/jpdf/tipp_2013_1_3.pdf [in Ukrainian].

8. Algero, M. (2005). The Sources of Law and the Value of Precedent: A Comparative and Empirical Study of a Civil Law State in a Common Law Nation. Louisiana Law Review. Vol. 65. P. 783. [in English].

9. Shevchuk, S. (2007). Sudova pravotvorchist: svitovyi dosvid ta perspektyvy v Ukrayini. [Judicial lawmaking: world experience and prospects in Ukraine]. Kyyiv: Referat. [in Ukrainian].

10. Reshota, V. V. (2015). Pravova pryroda rishen Verkhovnoho Sudu Ukrainy v administratyvnomu sudochynstvi u konteksti zabezpechennya prava na spravedlyvyy sud. [Legal nature of decisions of the Supreme Court of Ukraine in administrative proceedings in the context of ensuring the right to a fair trial]. Publichne pravo - Public Law, 2(18), 96-102. [in Ukrainian].

11. Maydanyk, R. A. (2012). Tsyvilne pravo: Zahalna chastyna. [Civil law: General Part]. K. : Alerta. [in Ukrainian].

12. Bekon, F. (1978). Sochineniya $\mathrm{v}$ dvukh tomakh [Works in two volumes]. Moskva: Mysl'. (Vol. 2). [in Russian].

13. Malyshev, B. V. (2002). Sudovyi pretsedent u pravovii systemi Anhlii (teoretykopravovyi aspekt) [Judicial precedent in the legal system of England (theoretical and legal aspect)]. Candidate's thesis. Kyiv. [in Ukrainian]. 
14. Zhuravlov, A. V. (2017). Sudovyi pretsedenty $\mathrm{v}$ administratyvnomu sudochynstvi Ukrainy [Judicial precedents in the administrative proceedings of Ukraine]. $E x$ tended abstract of candidate's thesis. Zaporizhzhia: ZNU. [in Ukrainian].

15. Reshota, V. V. (2019). Zastosuvannia dzherel administratyvnoho prava $\mathrm{V}$ sudochynstvi Ukrainy [Application of sources of administrative law in the judiciary of Ukraine]. Doctor's thesis. Lviv. [in Ukrainian].

16. Reutov, V. P. (2015). O yuridicheskoy prirode i vidakh predpisaniy, soderzhashchikhsya v aktakh vysshikh sudebnykh organov [On the legal nature and types of prescriptions contained in the acts of the highest judicial authorities]. Konkretizatsiya prava: teoreticheskiye i prakticheskiye problemy : materialy IX Mezhdunarodnoy nauchno-prakticheskoy konferentsii - Concretization of law: theoretical and practical problems : Proceedings of the IX International Scientific and Practical Conference. (pp.332-341). M.: RGUP. [in Russian].

17. Shevchuk, S. V. (2006) Rishennia Verkhovnoho Sudu Ukrainy yak dzherelo prava (deiaki aspekty dii pretsedentnoho prava v Ukraini). [Judgment of the Supreme Court of Ukraine as a source of law (some aspects of the case law in Ukraine)]. Visnyk tsentru suddivskykh studii - Bulletin of the Centre for Judicial Studie, 6, 16-19. [in Ukrainian].

18. Luspenik, D. (2004). Otechestvennaya sudebnaya praktika kak dopolnitel'nyy istochnik prava [Domestic judicial practice as an additional source of law]. Yuridicheskaya praktika - Ukrainian Law, 23 (337), 10-12. [in Russian].

19. Spasybo-Fatieieva, I. V. (2012). Tsyvilistyka: na shliakhu formuvannia doktryn [Civil law: on the way to the formation of doctrines]. Kharkiv: Zoloti storinky. [in Ukrainian].

20. Spasibo-Fateyeva, I. V. (2000). Nekotoryye podkhody k ponyatiyu istochnikov prava: v poryadke postanovki problemy [Some approaches to the concept of sources of law: in the order of posing the problem]. Problemy zakonnosti - Problems of legality, Issue 42, 4954. Kharkiv. [in Russian / in Ukrainian].

21. Shyshka, O. R. (2019). Vysnovky verkhovnoho sudu Ukrainy yak «dzherelo» tsyvilnoho prava : deiaki vrazlyvosti ta problemy nespivpadinnia z kontseptom TSK Ukrainy [Conclusions of the Supreme Court of Ukraine as a "source" of civil law: some vulnerabilities and problems of inconsistency with the concept of the Central Committee of Ukraine]. Problemy tsyvilnoho prava ta protsesu : tezy dop. uchasnykiv nauk.-prakt. konf., prysviach. svitlii pamiati O. A. Pushkina - Problems of civil law and procedure: Abstracts of Papers of participants of the scientific and practical conference dedicated to the bright memory of $\mathrm{O}$. A. Pushkin. (pp.217-222). Kharkiv: KHNUVS. [in Ukrainian].

22. Cardozo, B. N. (1921). The Nature of the Judicial Process. New Haven: Yale University Press. [in English]

23. Shyshka, O. R. (2020). Kontsept termina «zakon» u praktytsi YESPL [The concept of the term "law" in the practice of the ECHR]. Pidhotovka politseiskykh v umovakh reformuvannia systemy MVS Ukrainy : zb. nauk. pr. konf. MVS Ukrainy - Training of police officers in the context of reforming the system of the MIA of Ukraine : Collection of the Scientific and Practical Conference. (pp.54-56). Kharkiv : KHNUVS. [in Ukrainian].

24. Sanoma Uitgevers B.V. v. the Netherlands, no. 38224/03, ECHR, 14 September. Retrieved from http://hudoc.echr. coe.int/eng?i=001-100448. [in English].

25. Huvig v. Frence, no. 11105/84, ECHR, 24 April 1990. Retrieved from http://hudoc. echr.coe.int/eng?i=001-57627. [in English].

26. Jacobs, F. G., \& White, R. C. A. (1996). The European Convention on Human Rights. Oxford, 1996. P. 303. [in English].

27. Shyshka, O. R. (2020). Tsyvilne zakonodavstvo Ukrainy ta yoho mezhi [Civil legislation of Ukraine and its limits]. Rekodyfikatsiia tsyvilnoho zakonodavstva Ukrainy $\mathrm{v}$ umovakh yevrointehratsiinykh protsesiv : monohrafiia - Recodification of the civil legislation of Ukraine in the conditions of European integration processes : monograph. (pp.177-207). Kyiv : Norma prava. [in Ukrainian].

28. Shyshka, O. R. (2020). Civil legislation of Ukraine and its limits. Current issues of recodification of Ukrainian civil legislation : collective monograph. (pp.104117). Lviv-Toruń : Liha-Pres. [in English]. 


\section{Цивільне, підприсмницьке, господа \\ THE ROLE OF JUDICIAL PRACTICE OF THE SUPREME COURT IN THE PROCESS OF LAW ENFORCEMENT OF GIVIL LAW NORMS}

In the article, based on the analysis of the norms of current civil legislation, the legal position of the European Court of human rights and scientific approaches of domestic and foreign scientists, analyzes and determines the place and role of judicial practice of the Supreme Court in the process of law enforcement of civil law norms. It is concluded that the judicial practice of the Supreme Court plays an important role in the process of law enforcement of civil law norms, however, in comparison with civil law norms, their role is secondary. Based on the fact that according to the Civil Code of Ukraine, the judicial practice of the Supreme Court does not belong to the sources of civil law, this gave the author grounds to argue that such a court does not have the ability to carry out rulemaking, in particular, to create, change or cancel civil law norms. It is proved that the Supreme Court is only endowed with the ability to conduct an official interpretation (explanation) of legal norms, and its judicial practice is official acts of judicial interpretation (explanation) of legal norms.
It is established that the main role of the judicial practice of the Supreme Court is to eliminate manifestations of legal uncertainty in law enforcement. It is proved that such judicial practice contributes to the implementation of the principle of equality of all citizens before the law and the court, and it also ensures the future constancy and unity of judicial practice.

It is revealed that the legal position of the Supreme Court, which of actually acquires the characteristics of a norm of law, hers should be considered as incompatible with the principle of the rule of law, as hers regulatory force creates a state of legal uncertainty in law.

Keywords: rule of law, judicial practice, Supreme Court, civil law norm, acts of judicial interpretation (explanation) of legal norms. 